\title{
Effect of an aqueous extract of Phaseolus vulgaris on the properties of tail tendon collagen of rats with streptozotocin-induced diabetes
}

L. Pari and

S. Venkateswaran
Department of Biochemistry, Faculty of Science,

Annamalai University, Annamalainagar, Tamil Nadu, India
Correspondence

\section{Pari}

Department of Biochemistry

Faculty of Science

Annamalai University

Annamalainagar-608 002

Tamil Nadu

India

Fax: +91-4144-23-8145

E-mail: paribala@sancharnet.in

Research supported by the Indian Council of Medical Research, New Delhi (No. 45/29/99 - BMS) in the form of a senior research fellowship to $\mathrm{S}$. Venkateswaran. $\ldots \ldots \ldots \ldots \ldots \ldots$

Received November 13, 2002 Accepted April 14, 2003

\begin{abstract}
Changes in the structural and functional properties of collagen caused by advanced glycation might be of importance for the etiology of late complications in diabetes. The present study was undertaken to investigate the influence of oral administration of aqueous pod extract (200 $\mathrm{mg} / \mathrm{kg}$ body weight) of Phaseolus vulgaris, an indigenous plant used in Ayurvedic Medicine in India, on collagen content and characteristics in the tail tendon of streptozotocin-diabetic rats. In diabetic rats, collagen content (117.01 $\pm 6.84 \mathrm{mg} / 100 \mathrm{mg}$ tissue) as well as its degree of cross-linking was increased, as shown by increased extent of glycation $(21.70 \pm 0.90 \mu \mathrm{g}$ glucose $/ \mathrm{mg}$ collagen $)$, collagen-linked fluorescence $(52.8 \pm 3.0 \mathrm{AU} / \mu \mathrm{mol}$ hydroxyproline), shrinkage temperature $\left(71.50 \pm 2.50^{\circ} \mathrm{C}\right)$ and decreased acid $(1.878 \pm 0.062 \mathrm{mg}$ hydroxyproline $/ 100 \mathrm{mg}$ tissue $)$ and pepsin solubility $(1.77 \pm 0.080 \mathrm{mg}$ hydroxyproline $/ 100 \mathrm{mg}$ tissue). The $\alpha / \beta$ ratio of acid- (1.69) and pepsin-soluble (2.00) collagen was significantly decreased in streptozotocin-diabetic rats. Administration of $P$. vulgaris for 45 days to streptozotocin-diabetic rats significantly reduced the accumulation and cross-linking of collagen. The effect of $P$. vulgaris was compared with that of glibenclamide, a reference drug administered to streptozotocin-diabetic rats at the dose of $600 \mu \mathrm{g} / \mathrm{kg}$ body weight for 45 days by gavage. The effects of $P$. vulgaris (collagen content, $64.18 \pm 1.97$; extent of glycation, $12.00 \pm 0.53$; collagen-linked fluorescence, $33.6 \pm$ 1.9; shrinkage temperature, $57.0 \pm 1.0$; extent of cross-linking - acidsoluble collagen, $2.572 \pm 0.080$, and pepsin-soluble collagen, $2.28 \pm$ 0.112 ) were comparable with those of glibenclamide (collagen content, $71.5 \pm 2.04$; extent of glycation, $13.00 \pm 0.60$; collagen-linked fluorescence, $38.9 \pm 2.0$; shrinkage temperature, $59.0 \pm 1.5$; extent of cross-linking - acid-soluble collagen, $2.463 \pm 0.078$, and pepsinsoluble collagen, $2.17 \pm 0.104)$. In conclusion, administration of $P$. vulgaris pods had a positive influence on the content of collagen and its properties in streptozotocin-diabetic rats.
\end{abstract}

Key words - Collagen - Diabetes - Phaseolus vulgaris

- Cross-linking - Glibenclamide - Collagen glycation 


\section{Introduction}

Collagen is a major component of mammalian connective tissue and is present in all major tissues that require strength and flexibility such as skin, bone and tendon (1). Type I collagen is the principal extracellular matrix protein (2). Collagens are characterized by the presence of one or more triple helix domains. The helical structure consists of polypeptide chains containing Gly-x-y repeats, where $\mathrm{x}$ and $\mathrm{y}$ typically represent proline or hydroxyproline residues. Collagen molecules, after being secreted by the cells, assemble into characteristic fibers responsible for the functional integrity of tissues such as bone, cartilage, skin and tendon. They provide a structural framework for other tissues, such as blood vessels, aorta and most organs. Cross-links between adjacent molecules are a prerequisite for the collagen fibers to withstand the physical stresses to which they are exposed $(3,4)$.

Nonenzymatic glycation of collagen leading to the formation of advanced glycation end products is increased in patients with diabetes mellitus and in animals with experimental diabetes (5). Changes in the structural and functional properties of proteins caused by advanced glycation might be of importance for the etiology of late complications in diabetes. The process of nonenzymatic glycation is initiated by covalent binding of the reactive aldehyde moiety of glucose to free amino groups of protein (6). Collagenous proteins are especially exposed to glycation because they contain several lysine, hydroxyl lysine and arginine residues with free amino groups, have a very slow turnover rate and are exposed to ambient levels of glucose $(7,8)$. The content of advanced glycation end products in collagen increases with age and diabetes (8).

In recent years the popularity of alternative medicine has increased for various reasons. Dietary measures and traditional plant therapies as prescribed by Ayurvedic and other indigenous medicine systems are commonly used in India (9). The beneficial actions of these diets on the amelioration of diabetic symptoms are well documented $(10,11)$.

Phaseolus vulgaris L. (Leguminosae), commonly known as kidney bean, is a food item of mass consumption in Asia and Eastern countries. The various parts of the plant have been extensively used in Ayurvedic and Unani practice on the Indian subcontinent for the treatment of diabetes mellitus (12). In 1995, Roman-Ramos et al. (13) showed that the aqueous extract of $P$. vulgaris pods possessed antihyperglycemic activity. P. vulgaris has also been reported to contain nearly $50 \mathrm{mg}$ of flavonoids per $100 \mathrm{~g}$ (14). Recently we have demonstrated the antioxidant (15) and hypolipidemic (16) effects of $P$. vulgaris pods in diabetic rats.

To our knowledge, the present investigation is the first report on the effects of $P$. vulgaris extracts on the collagen content and its physical and chemical characteristics in the tail tendon of streptozotocin-diabetic rats.

\section{Material and Methods}

\section{Experimental animals}

Male albino Wistar rats weighing 170$200 \mathrm{~g}$ bred in the Central Animal House, Rajah Muthiah Medical College, were used. The animals received a normal laboratory pellet diet (Hindustan Lever Ltd., Mumbai, India) and water ad libitum. The animals used in the present study were maintained in accordance with the guidelines of the National Institute of Nutrition, Indian Council of Medical Research, Hyderabad, India. The study was approved by the Ethics Committee of Annamalai University.

\section{Drugs and chemicals}

All drugs and biochemicals used in this study were purchased from Sigma (St. Louis, 
MO, USA). The chemicals were of analytical grade or equivalent.

\section{Plant material}

P. vulgaris was purchased on the local market in Chidambaram, Cuddalore District, Tamil Nadu, India. The plant was identified in the herbarium of the Botany Directorate of Annamalai University. A voucher specimen (No. 2387) was deposited in the Botany Department of Annamalai University.

\section{Preparation of plant extract}

One hundred and thirty-two grams of dried $P$. vulgaris pods was extracted with 1.0 liter of water for $2 \mathrm{~h}$ at $60-70^{\circ} \mathrm{C}$ by continuous hot extraction and evaporated to dryness in a rotary evaporator at $40-50^{\circ} \mathrm{C}$ under reduced pressure. A semisolid material was obtained $(20 \mathrm{~g})$ and stored at $0-4^{\circ} \mathrm{C}$ until the time for use. When needed, the residual extract was suspended in distilled water and used in the study (13).

\section{Induction of experimental diabetes}

A freshly prepared solution of streptozotocin $(45 \mathrm{mg} / \mathrm{kg})$ in $0.1 \mathrm{M}$ citrate buffer, $\mathrm{pH}$ 4.5 , was injected intraperitoneally in a volume of $1 \mathrm{ml} / \mathrm{kg}$ (17). Forty-eight hours after streptozotocin administration, rats with moderate diabetes having glycosuria and hyperglycemia (i.e., with blood glucose of 200$300 \mathrm{mg} / \mathrm{dl}$ ) were used for the experiment.

\section{Experimental procedure}

A total of 40 rats (30 surviving diabetic rats and 10 normal rats) were used. The rats were divided into 4 groups of 10 rats each. Group 1: normal untreated rats; group 2: diabetic control rats; group 3: diabetic rats receiving the $P$. vulgaris pod extract (200 $\mathrm{mg} / \mathrm{kg}$ body weight) in $1 \mathrm{ml}$ aqueous solution daily by gavage for 45 days (13); group
4: diabetic rats receiving glibenclamide $(600$ $\mu \mathrm{g} / \mathrm{kg}$ body weight) in aqueous solution daily by gavage for 45 days (18).

After 45 days, the animals were deprived of food overnight and sacrificed by decapitation. Blood was collected with potassium oxalate and sodium fluoride as anticoagulants for the determination of blood glucose. Plasma was separated by centrifugation for insulin assay. The tail was removed and stored frozen at $-80^{\circ} \mathrm{C}$ and tail tendon tissue was prepared as described below.

\section{Blood glucose and plasma insulin}

Fasting blood glucose was measured by the O-toluidine method (19) and plasma insulin was assayed with an ELISA kit (Boehringer-Mannheim, Mannheim, Germany).

\section{Preparation and purification of type I collagen}

Collagen was purified by the method described by Chandrakasan et al. (20). Briefly, tail tendons were dissected free, washed extensively in phosphate-buffered saline (PBS) and extracted. The entire procedure was carried out at $0-5^{\circ} \mathrm{C}$. Tail tendons obtained from rats were washed with neutral $1 \% \mathrm{NaCl}$ and extracted by stirring overnight in eight volumes (v/v) of $0.5 \mathrm{M}$ acetic acid. The suspension was centrifuged at 28,330 $\mathrm{g}$ for $30 \mathrm{~min}$ and the pellet was re-extracted with acetic acid. The supernatant solutions were combined and solid $\mathrm{NaCl}$ was added slowly with stirring to reach $20 \%$ concentration $(\mathrm{w} / \mathrm{v})$. The precipitate obtained was collected by centrifugation at $17,000 \mathrm{~g}$ for $30 \mathrm{~min}$ and the pellet was washed three times by resuspending in $20 \% \mathrm{NaCl}$ and recentrifuged. The washed pellet was then suspended in three volumes of $0.5 \mathrm{M}$ acetic acid, stirred for a few hours and then dialyzed overnight against several volumes of $0.5 \mathrm{M}$ acetic acid with at least one change. The solution was centrifuged at 28,330 $\mathrm{g}$ for $3 \mathrm{~min}$. Collagen was 
precipitated from the supernatant by slow addition with stirring of 0.2 volumes $30 \%$ $\mathrm{NaCl}$ in $0.5 \mathrm{M}$ acetic acid. The washed pellet was suspended in two volumes of $0.5 \mathrm{M}$ acetic acid and dialyzed overnight against several changes of $20 \mathrm{mM} \mathrm{Na} \mathrm{HPO}_{4}$. The precipitate was collected by centrifugation at $17,000 \mathrm{~g}$ for $30 \mathrm{~min}$, washed once with 20 $\mathrm{mM} \mathrm{Na}_{2} \mathrm{HPO}_{4}$ and redissolved in two volumes of $0.5 \mathrm{M}$ acetic acid. The solution was centrifuged at 28,330 $\mathrm{g}$ for $60 \mathrm{~min}$ and dialyzed for 2 days against $0.1 \mathrm{M}$ acetic acid with three changes. The purified collagen was lyophilized and stored in a freezer in containers sealed under vacuum.

\section{Estimation of collagen content}

Weighed tail tendon tissue was hydrolyzed in $6.0 \mathrm{~N} \mathrm{HCl}$ for $18 \mathrm{~h}$ at $110^{\circ} \mathrm{C}$. The collagen content was determined by measuring hydroxyproline, as described by Woessner (21).

\section{Extent of glycation}

The extent of glycation was determined by the method described by Rao and Pattabiraman (22) in which $1.0 \mathrm{ml}$ of purified collagen (containing $1.0 \mathrm{mg}$ collagen) was mixed with $3.0 \mathrm{ml}$ of concentrated $\mathrm{H}_{2} \mathrm{SO}_{4}$, vortexed, cooled on ice, mixed with $0.5 \mathrm{ml}$ of $80 \%$ phenol, and left to stand at room temperature for $30 \mathrm{~min}$. Absorbance was measured at $485 \mathrm{~nm}$ using glucose as standard.

\section{Collagen-linked fluorescence}

Collagen-linked fluorescence was measured by the method of Monnier et al. (23). Approximately $3.0 \mathrm{mg}$ tissue was finely minced in PBS and centrifuged at 3,330 $g$ for $10 \mathrm{~min}$. The pellet was washed with distilled water and the lipids were extracted with 5.0 $\mathrm{ml}$ of chloroform:methanol $(2: 1, \mathrm{v} / \mathrm{v})$ overnight. The samples were rehydrated by the addition of $2.0 \mathrm{ml}$ methanol and $0.5 \mathrm{ml}$ distilled water and centrifuged at $3,330 \mathrm{~g}$ for $10 \mathrm{~min}$ and the pellet was washed twice with methanol, three times with distilled water, twice with $20 \mathrm{mM} \mathrm{N}$-[2-hydroxyethyl] piperazine-N'-[2-ethanesulfonic acid], $\mathrm{pH}$ 7.5, containing $0.12 \mathrm{M} \mathrm{CaCl}_{2}$ (buffer $\mathrm{H}$ ) and stored overnight at $4^{\circ} \mathrm{C}$ in buffer $\mathrm{H}$. The buffer was then removed by centrifugation at $3,330 \mathrm{~g}$ for $10 \mathrm{~min}$ and the pellet resuspended in $3.5 \mathrm{ml}$ of buffer $\mathrm{H}$ containing 120 units of type VII collagenase. Four drops of toluene were added to prevent bacterial growth and the material was digested for $48 \mathrm{~h}$ at $37^{\circ} \mathrm{C}$. A blank containing collagenase in buffer $\mathrm{H}$ was included. The digest was centrifuged at 3,330 $\mathrm{g}$ for $30 \mathrm{~min}$ and the clear supernatant containing digested collagen was used for the fluorescence assay. Fluorescence was measured with a Hitachi spectrofluorometer (Hitachi, Tokyo, Japan) against distilled water at $440 \mathrm{~nm}$ after excitation at $370 \mathrm{~nm}$ and was corrected for the collagenase blank.

\section{Solubility pattern of tail tendon collagen}

The solubility pattern of tail tendon collagen was determined as described by Miller and Rhodes (24).

\section{Neutral salt-soluble collagen}

Tail tendon tissue was thoroughly minced, homogenized in 10 volumes of neutral salt solvent (1.0 M NaCl, $50 \mathrm{mM}$ Tris, $\mathrm{pH} 7.5)$ containing $20 \mathrm{mM}$ EDTA and $2.0 \mathrm{mM} \mathrm{N}$ ethyl maleimide and stirred for $24 \mathrm{~h}$. The suspension was then centrifuged at $35,000 \mathrm{~g}$ for $1 \mathrm{~h}$ at $4^{\circ} \mathrm{C}$ and the extraction was repeated with the pellet. The supernatants were pooled and an aliquot was used for the assay of hydroxyproline (21).

\section{Acid-soluble collagen}

The residue obtained was resuspended in 
10 volumes of $0.5 \mathrm{M}$ acetic acid and extracted for $24 \mathrm{~h}$ with constant stirring, after which the contents were centrifuged. The pellet was re-extracted with acetic acid, the supernatants were pooled and an aliquot was used for the determination of hydroxyproline.

\section{Pepsin-soluble collagen}

The residue obtained after acid extraction was resuspended in $0.5 \mathrm{M}$ acetic acid containing $100 \mathrm{mg}$ pepsin per $\mathrm{g}$ wet tissue. Digestion was carried out for $24 \mathrm{~h}$, followed by centrifugation and re-extraction. Aliquots of pooled supernatant were used for hydroxyproline measurement.

\section{Shrinkage temperature}

The shrinkage temperature of tail tendon collagen was determined as described by Nutting and Borasky (25). Small strips of collagen fibers were cut from the tail tendon and placed on microscope slides mounted on a holder for viewing under the microscope. An electric bulb with heat-producing capacity was placed under the holder. A thermometer was inserted into the hole available in the holder to monitor the temperature. The electric bulb was then switched on and the heating rate was set at $3^{\circ} \mathrm{C} / \mathrm{min}$. The shrinkage temperature of collagen fibers was monitored through the microscope and the exact shrinkage temperature was recorded during the shrinkage process (26).

\section{SDS-PAGE}

Acid- and pepsin-soluble collagen was prepared from tail tendon as described by Miller and Rhodes (24). Collagen samples were investigated by SDS-PAGE using a 3\% stacking gel with a $5 \%$ running gel and Coomassie brilliant blue staining. The gels were scanned with a densitometer and the $\alpha / \beta$ ratio of acid- and pepsin-soluble collagen was calculated.

\section{Statistical analysis}

The data for the various biochemical parameters were analyzed by analysis of variance (ANOVA) and the group means were compared by Duncan's multiple range test (27). Values were considered statistically significant when $\mathrm{P}<0.05$.

\section{Results}

\section{Blood glucose and plasma insulin}

Blood glucose and plasma insulin levels of normal and experimental rats are given in Table 1. The diabetic rats showed a significant increase in blood glucose and a significant decrease in plasma insulin levels. The administration of Phaseolus pod extract and glibenclamide to diabetic rats caused a significant decrease in blood glucose levels and a significant increase in plasma insulin. However, neither the plant extract nor glibenclamide normalized glucose or insulin levels completely.

The dose of $P$. vulgaris $(200 \mathrm{mg} / \mathrm{kg}$ body weight) was selected based on our previous studies in which a dose-dependent effect of $P$. vulgaris on blood glucose was obtained. P. vulgaris was studied with three different doses - 50, 100 and $200 \mathrm{mg} / \mathrm{kg}$ body weight. Among the three different doses, P. vulgaris showed a highly significant effect at $200 \mathrm{mg} /$ $\mathrm{kg}$ body weight $(15,16)$. So we have chosen

Table 1. Effect of Phaseolus vulgaris pod extract (PPEt) on blood glucose and plasma insulin levels in normal and diabetic rats.

\begin{tabular}{lcc}
\hline Group & Blood glucose $(\mathrm{mg} / \mathrm{dl})$ & Plasma insulin $(\mu \mathrm{U} / \mathrm{ml})$ \\
\hline Normal & $79.12 \pm 5.42^{\mathrm{a}}$ & $14.41 \pm 0.70^{\mathrm{a}}$ \\
Diabetic control & $278.40 \pm 22.00^{\mathrm{b}}$ & $4.13 \pm 0.26^{\mathrm{b}}$ \\
Diabetic + PPEt & $91.20 \pm 4.65^{\mathrm{c}}$ & $7.78 \pm 0.40^{\mathrm{c}}$ \\
Diabetic + glibenclamide & $98.20 \pm 6.50^{\mathrm{d}}$ & $7.50 \pm 0.34^{\mathrm{c}}$ \\
\hline
\end{tabular}

PPEt $(200 \mathrm{mg} / \mathrm{kg})$ and glibenclamide $(600 \mu \mathrm{g} / \mathrm{kg})$ were administered by gavage daily for 45 days. Data are reported as means \pm SD for 6 rats in each group. Values not sharing a common superscript letter differed significantly at $P<0.05$ (Duncan multiple range test). 
the dose for our present study. The effect of the dose was compared with glibenclamide at a dose of $600 \mu \mathrm{g} / \mathrm{kg}$ body weight, which is a well-accepted standardized dose in experimental animals. Glibenclamide is also known to cause severe side effects at doses higher than $600 \mu \mathrm{g} / \mathrm{kg}$ (18).

\section{Hydroxyproline, total collagen, extent of glycation, collagen-linked fluorescence and shrinkage temperature}

The data in Table 2 show that the levels of hydroxyproline and total collagen and the extent of glycation and collagen-linked fluorescence were significantly increased in diabetic animals. The shrinkage temperature was also increased in the diabetic group compared to the normal group. Administration of both Phaseolus pod extract and glibenclamide significantly reduced collagen levels, extent of glycation and collagen-linked fluorescence in diabetic rats. The increased shrinkage temperature was also significantly prevented in diabetic rats treated with $P$ haseolus pod extract and glibenclamide. The effect of the extract was almost similar to that of glibenclamide.

\section{Pattern of collagen solubility}

Data concerning the solubility pattern of tail tendon collagen of normal rats and of the experimental groups after extraction with neutral salt and acid solution and by pepsin digestion are presented in Table 3. The per-

Table 2. Effect of Phaseolus vulgaris pod extract (PPEt) on hydroxyproline, total collagen, extent of glycation, fluorescence and shrinkage temperature of rat tail collagen from normal and diabetic rats.

\begin{tabular}{|c|c|c|c|c|c|}
\hline Group & $\begin{array}{l}\text { Hydroxyproline } \\
\text { (mg/100 mg tissue) }\end{array}$ & $\begin{array}{c}\text { Total collagen } \\
\text { (mg/100 mg tissue) }\end{array}$ & $\begin{array}{l}\text { Extent of glycation } \\
\text { ( } \mu \mathrm{g} \text { glucose } / \mathrm{mg} \\
\text { collagen) }\end{array}$ & $\begin{array}{l}\text { Fluorescence } \\
\text { (AU/ } / \mathrm{mol} \\
\text { hydroxyproline) }\end{array}$ & $\begin{array}{c}\text { Shrinkage } \\
\text { temperature } \\
\left({ }^{\circ} \mathrm{C}\right)\end{array}$ \\
\hline Normal & $8.87 \pm 0.233^{a}$ & $66.13 \pm 1.14^{a}$ & $10.30 \pm 0.42^{a}$ & $27.7 \pm 1.3^{a}$ & $60.5 \pm 1.0^{\mathrm{a}}$ \\
\hline $\begin{array}{l}\text { Diabetic } \\
\text { control }\end{array}$ & $15.69 \pm 0.917^{b}$ & $117.01 \pm 6.84^{b}$ & $21.70 \pm 0.90^{b}$ & $52.8 \pm 3.0^{b}$ & $71.5 \pm 2.5^{b}$ \\
\hline $\begin{array}{l}\text { Diabetic + } \\
\text { PPEt }\end{array}$ & $9.68 \pm 0.265^{c}$ & $64.18 \pm 1.97^{c}$ & $12.00 \pm 0.53^{c}$ & $33.6 \pm 1.9^{c}$ & $57.0 \pm 1.0^{c}$ \\
\hline $\begin{array}{l}\text { Diabetic }+ \\
\text { glibenclamide }\end{array}$ & $9.59 \pm 0.254^{d}$ & $71.5 \pm 2.04^{d}$ & $13.00 \pm 0.60^{d}$ & $38.9 \pm 2.0^{d}$ & $59.0 \pm 1.5^{d}$ \\
\hline
\end{tabular}

For drug administration see Table 1 legend. $A U=$ arbitrary units. Data are reported as means \pm SD for 6 rats in each group. Values not sharing a common superscript letter differ significantly at $\mathrm{P}<0.05$ (Duncan multiple range test).

Table 3. Effect of Phaseolus vulgaris pod extract (PPEt) on neutral salt-, acid- and pepsin-soluble collagen content (hydroxyproline/100 $\mathrm{mg}$ tissue) of tail tendon in normal and diabetic rats.

\begin{tabular}{|c|c|c|c|}
\hline Group & $\begin{array}{l}\text { Neutral salt-soluble collagen } \\
\qquad(\mu \mathrm{g} / 100 \mathrm{mg})\end{array}$ & $\begin{array}{l}\text { Acid-soluble collagen } \\
\text { (mg/100 mg) }\end{array}$ & $\begin{array}{l}\text { Pepsin-soluble collagen } \\
\text { (mg/100 mg) }\end{array}$ \\
\hline Normal & $137.56 \pm 9.2^{a}$ & $2.895 \pm 0.091^{a}$ & $2.96 \pm 0.100^{a}$ \\
\hline Diabetic control & $71.99 \pm 4.2^{b}$ & $1.878 \pm 0.062^{b}$ & $1.77 \pm 0.080^{b}$ \\
\hline Diabetic + PPEt & $113.60 \pm 7.8^{c}$ & $2.572 \pm 0.080^{c}$ & $2.28 \pm 0.112^{c}$ \\
\hline Diabetic + glibenclamide & $101.40 \pm 7.4^{d}$ & $2.463 \pm 0.078^{d}$ & $2.17 \pm 0.104^{d}$ \\
\hline
\end{tabular}

For drug administration see Table 1 legend. Data are reported as means \pm SD for 6 rats in each group. Values not sharing a common superscript letter differed significantly at $P<0.05$ (Duncan multiple range test). 
centage of neutral salt-, acid- and pepsinsoluble collagen was significantly decreased in diabetic animals. Administration of the Phaseolus pod extract and glibenclamide significantly increased collagen solubility in diabetic rats.

\section{SDS-PAGE}

The gel patterns obtained by SDS-PAGE of acid- and pepsin-soluble collagen from the tail tendon of normal and experimental rats are shown in Figure 1. The $\alpha / \beta$ ratio of both acid- and pepsin-soluble collagen was decreased significantly in diabetic rats (Table 4). Administration of Phaseolus pod extract and glibenclamide significantly increased the $\alpha / \beta$ ratio to near normal values.

\section{Discussion}

We determined the influence of an ex-

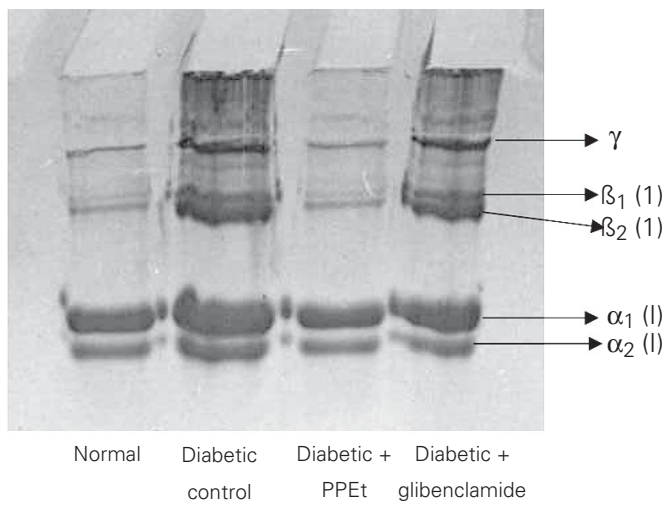

tract of $P$. vulgaris on collagen content and characteristics in diabetic rats.

The capacity of the Phaseolus pod extract to decrease the elevated blood sugar to normal levels is an essential trigger for the liver to revert to its normal homeostasis during experimental diabetes. The possible mechanism by which the plant extract exerts its hypoglycemic action in diabetic rats may be by potentiating the plasma insulin effect by increasing either the pancreatic secretion of insulin from the existing $\beta$-cells or its release from the bound form, as demonstrated by the significant increase in insulin levels induced by the plant extract in diabetic rats (Table 1).

Streptozotocin-induced diabetes mellitus characterized by hyperglycemia caused a significant increase in hydroxyproline levels and collagen content. The correlation between collagen and intracellular degradation is of interest and may have a role in the

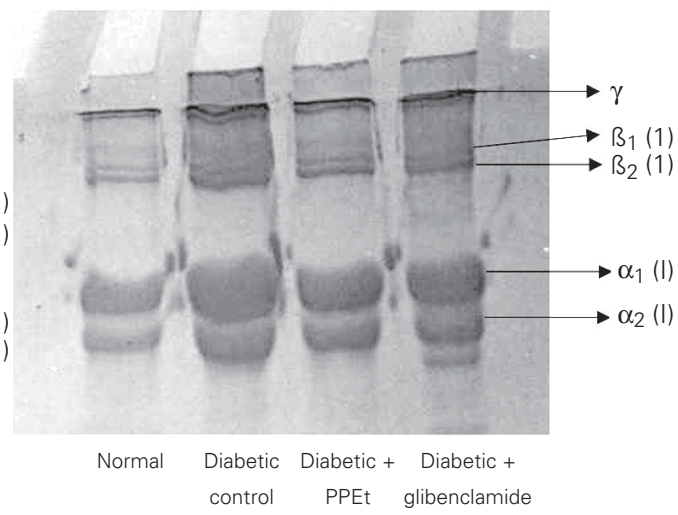

Table 4. Effect of Phaseolus vulgaris pod extract (PPEt) on the $\alpha / ß$ ratio of acid-and pepsin-soluble collagen in tail tendon of normal and diabetic rats.

\begin{tabular}{|c|c|c|c|c|c|c|}
\hline \multirow[t]{2}{*}{ Group } & \multicolumn{3}{|c|}{ Acid-soluble collagen component } & \multicolumn{3}{|c|}{ Pepsin-soluble collagen component } \\
\hline & $\alpha$ & ß & $\alpha / \beta$ ratio & $\alpha$ & $\beta$ & $\alpha / ß$ ratio \\
\hline Normal & 69.5 & 30.3 & $2.27^{a}$ & 73.1 & 26.9 & $2.71^{a}$ \\
\hline Diabetic control & 62.9 & 37.1 & $1.69^{b}$ & 66.7 & 33.3 & $2.00^{b}$ \\
\hline Diabetic + PPEt & 66.8 & 33.2 & $2.00^{c}$ & 69.4 & 30.6 & $2.26^{c}$ \\
\hline Diabetic + glibenclamide & 65.5 & 34.5 & $1.89^{d}$ & 66.5 & 33.5 & $1.98^{d}$ \\
\hline
\end{tabular}

For drug administration see Table 1 legend. Data are reported as means \pm SD for 6 rats in each group. Values not sharing a common superscript letter differed significantly at $\mathrm{P}<0.05$ (Duncan multiple range test).
Figure 1. Effect of Phaseolus vulgaris pod extract (PPEt) on SDS-PAGE pattern of acidsoluble (left) and pepsin-soluble (right) collagen of tail tendon in normal and diabetic rats. 
regulation of collagen content. Golub et al. (28) have suggested that increased degradation of newly synthesized collagen during streptozotocin-induced diabetes might contribute to collagen deposition in the early stages. Diabetic rats treated with the plant extract and glibenclamide showed a significant decrease in total collagen content when compared to untreated diabetic rats. This decrease may be attributed to the significant decrease in blood glucose and consequent decrease in nonenzymatic glycation and deposition of collagen in diabetic rats treated with the Phaseolus pod extract and glibenclamide. The extract exhibited effects similar to those of glibenclamide.

In addition, prolyl hydroxylase, an ascorbic acid-dependent enzyme, is required to maintain the normal properties of collagen. The activity of prolyl hydroxylase has been reported to change in diabetic rats (29). This alteration is mainly due to the reduction in the concentration of ascorbic acid in diabetes (29). In a previous study, we also observed a significant reduction in the concentration of ascorbic acid in streptozotocindiabetic rats (16). We also observed a significant increase in the concentration of ascorbic acid in diabetic rats treated with the plant extract and glibenclamide (16). The decrease in the ascorbic acid concentration and consequently altered prolyl hydroxylase could also be responsible for the alteration of collagen observed in streptozotocin-diabetic rats. A significant increase in the concentration of ascorbic acid in diabetic rats treated with the plant extract and glibenclamide (16) may also be responsible for the significant reduction in collagen content.

In the present study, an increase in the extent of glycation was observed in the tail tendon of diabetic rats, probably due to exposure of the tissues to glucose in the diabetic state. Earlier studies have also reported that glucose is directly involved in the accelerated cross-linking of collagen in the diabetic state. Several studies have also estab- lished that collagen glycation is increased during exposure to high glucose levels in vitro and in vivo (30). Flavonoids were reported to have antiglycating activity (31). The decrease in the extent of glycation in diabetic rats treated with the plant extract could be due to the antiglycating property of the flavonoids present in the extract.

The cross-linking of tail tendon collagen was assessed by measuring the shrinkage temperature. The shrinkage temperature of collagen fibers is related to the number of covalent cross-links present in collagen and to the content of imino acids such as proline and hydroxyproline (32). The shrinkage temperature of collagen was reported to increase with age and in diabetes and was explained in terms of intermolecular cross-links (32). Therefore, the measurement of collagen shrinkage temperature may be used to determine the gross tissue changes at the molecular level.

We observed a significant increase in the collagen shrinkage temperature in diabetic rats, clearly indicating the increase in the cross-links of tail tendon collagen in these animals. Administration of the plant extract and glibenclamide induced a significant reduction in the cross-linking of tail tendon collagen.

The percentage of neutral salt-, acid- and pepsin-soluble collagen was decreased in the tail tendon of diabetic rats. As crosslinking proceeds, the solubility of collagen in neutral buffer and acid solution also changes. Highly cross-linked collagen becomes less soluble in the above solutions and can be released only by limited pepsin digestion (33). It has been proposed that free radicals and reactive carbonyls generated during diabetes may contribute significantly to the increased cross-linking of collagen $(34,35)$. From the solubility patterns obtained for collagen of tail tendon tissues of Phaseolus pod extract-treated and -untreated diabetic rats, it can be seen that the plant extract treatment resulted in increased solubility in 
neutral, acid and pepsin digestion. This is an indication of decreased levels of cross-linking in the collagen of the treated groups. The reduction in the advanced glycation and cross-linking of collagen in diabetic rats treated with the plant extract may be due to its antiperoxidative activity (15), since lipid peroxidation products have been shown to directly influence collagen cross-linking and advanced glycation end product formation $(36,37)$. In addition, advanced glycation end products were also reported to induce the upregulation of the expression of type I collagen genes that could result in excess deposition of collagen in diabetes (38). The increase in advanced glycation end product levels in diabetic rats observed in the present study could be responsible for the upregulation of collagen gene expression which results in the increased deposition of collagen and consequent increased cross-linking in streptozotocin-diabetic rats. The Phaseolus pod extract is reported to be rich in flavonoids. These flavonoids may contribute by their protective action to the reduction of collagen cross-linking in treated diabetic rats.

Collagen obtained from the tail tendon of diabetic animals showed increased fluorescence, which is a strong indication of increased advanced glycation. Previous studies have also documented an overall increase in the fluorescence of diabetic tissue collagen $(39,40)$. The $370 / 440 \mathrm{~nm}$ fluorescence is usually due to Maillard reaction-related fluorescence (6).

It has been shown that, in addition to glucose, free radicals and lipid peroxides also play an important role in the development of collagen-linked fluorescence (41). It appears that the reactive radicals formed during glycation and oxidation reactions can also have an influence on the development of fluorescence.

Administration of the Phaseolus pod extract and glibenclamide significantly reduced the intensity of fluorescence in diabetic rats. This may be due to the significant reduction in blood glucose and consequent decreased glycation, and to the significant scavenging of free radicals generated during diabetes by flavonoids present in Phaseolus pod extract.

The increased band size of $ß$-components in diabetic collagen clearly indicates the increased cross-linking. Golub et al. (28) have also reported that the acid-soluble collagen from streptozotocin-diabetic rats contains higher than normal amounts of $\beta$-component and hence exhibits increased cross-linking. The increased intensity of the $\beta$-component observed here in diabetic rats suggests that collagen chains are capable of enhanced intramolecular cross-linking since the $\beta$-component is a dimer of $\alpha$-chains. In diabetic rats treated with the Phaseolus pod extract, collagen content in the $\beta$-region as well as in the high molecular weight region was near normal when compared to diabetic control groups.

On the basis of these observations, it is clear that the $P$. vulgaris pod extract had a positive influence on the content of collagen and its characteristics in streptozotocin-diabetic rats. Further work is currently underway to analyze the components of the aqueous extract of $P$. vulgaris for their beneficial effects on collagen content in streptozotocin-diabetic rats.

\section{References}

1. Prockop DJ \& Kivirikko KI (1995). Collagens. Molecular biology, diseases and potentials for therapy. Annual Review of Biochemistry, 64: 403-434.

2. George A, Malone JP \& Veis A (1999). The secondary structure of type I collagen N-telopeptide as demonstrated by Fourier transform IR spectroscopy and molecular modeling. Proceedings of the Indian
Academy of Sciences (Chemical Sciences), 111: 121-131

3. Nimni ME \& Han BO (1999). Collagen and collagen-glycosaminoglycan matrices as carriers for growth factors. Proceedings of the Indian Academy of Sciences (Chemical Sciences), 111: 283-289.

4. Brown JC \& Timpl R (1995). The collagen superfamily. International Archives of Allergy and Immunology, 107: 484-490. 
5. Vlassara H, Bucala R \& Striker L (1994). Pathogenic effects of advanced glycosylation: biochemical, biologic, and clinical implications for diabetes and ageing. Laboratory Investigation, 70: 138-151.

6. Njoroge FG \& Monnier VM (1989). The chemistry of the Maillard reaction under physiological conditions: a review. In: Baynes JW \& Monnier VM (Editors), The Maillard Reaction and Aging, Diabetes and Nutrition. AR Liss, New York.

7. Brownlee M, Cerami A \& Vlassara H (1988). Advanced glycosylation end products in tissue and the biochemical basis of diabetic complications. New England Journal of Medicine, 318: 1315-1321.

8. Reiser KM (1998). Non-enzymatic glycation of collagen in aging and diabetes. Proceedings of the Society for Experimental Biology and Medicine, 218: 23-37

9. Warier PK (1995). Eugenia jambolana Linn. In: Warier PK, Nambiar VPK \& Ramankutty C (Editors), Indian Medicinal Plants. Orient Longman, Madras, India.

10. Bordia A, Verma SK \& Srivastava KC (1997). Effect of ginger (Zingiber officinale Rosc.) and fenugreek (Trigonella foenumgraecum L.) on blood lipids, blood sugar and platelet aggregation in patients with coronary artery disease. Prostaglandins, Leukotrienes, and Essential Fatty Acids, 56: 379-384.

11. Khan A \& Safdar M (2003). Role of diet, nutrients, spices and natural products in diabetes mellitus. Pakistan Journal of Nutrition, 2: 1-12.

12. Chopra RN, Chopra IC, Handa KI \& Kapur LD (1958). Medicinal plants in diabetes. In: Gupta P (Editor), Indigenous Drugs of India. 2nd edn. U.N. Dhar \& Sons Ltd., Calcutta, India.

13. Roman-Ramos R, Flores-Sanoz JL \& Alarcon-Aguilar FJ (1995). Antihyperglycemic effect of some edible plants. Journal of Ethnopharmacology, 48: 25-32.

14. Sushmita N \& Ranjana N (1997). Anti-oxidant flavonoids in common Indian foods. South Asian Journal of Preventive Cardiology, 1: 33-35.

15. Venkateswaran S \& Pari L (2002). Antioxidant effect of Phaseolus vulgaris in streptozotocin induced diabetic rats. Asia Pacific Journal of Clinical Nutrition, 11: 206-209.

16. Venkateswaran S, Pari L \& Saravanan G (2002). Effect of Phaseolus vulgaris on circulatory antioxidants and lipids in streptozotocin induced diabetic rats. Journal of Medicinal Food, 5: 97-103.

17. Siddique O, Sun Y, Lin JC \& Chien YW (1987). Facilitated transdermal transport of insulin. Journal of Pharmaceutical Sciences, 76: 341-345.

18. Pari L \& Umamaheswari J (2000). Antihyperglycaemic activity of Musa sapientum flowers: Effect on lipid peroxidation in alloxan diabetic rats. Phytotherapy Research, 14: 136-138.

19. Sasaki T, Matsy S \& Sonae A (1972). Effect of acetic acid concentration on the colour reaction in the O-toluidine boric acid method for blood glucose. Rinshbo Kagaku, 1: 346-353.

20. Chandrakasan G, Torchia DA \& Piez KA (1976). Preparation of intact monomeric collagen from tail tendon and skin and the structure of the nonhelical ends in solution. Journal of Biological Chemistry, 251: 6062-6067.

21. Woessner JF (1961). The determination of hydroxyproline in tissue and protein samples containing small portions of this imino acid. Archives of Biochemistry and Biophysics, 93: 440-447.

22. Rao P \& Pattabiraman TN (1989). Reevaluation of the phenol sulphuric acid reaction for the estimation of hexoses and pentoses. Analytical Biochemistry, 181: 18-22.

23. Monnier VM, Vishwanath $V$, Frank KE, Elmets CA, Dauchot $P$ \& Kohn RR (1986). Relation between complications of type I diabetes mellitus and collagen-linked fluorescence. New England Journal of Medicine, 314: 403-408.

24. Miller EJ \& Rhodes RK (1982). Preparation and characterization of different types of collagen. Methods in Enzymology, 82: 33-64.

25. Nutting GC \& Borasky R (1949). Microscopic methods for determining shrinkage temperature of collagen and leather. Journal of the American Leather Chemists Association, 44: 831-839.

26. Vangsness CT, Mitchell W, Nimni M, Erlich M, Saadat V \& Schmotzer H (1997). Collagen shortening. An experimental approach with heat. Clinical Orthopaedics, 337: 267-271.

27. Duncan BD (1957). Multiple range tests for correlated and heteroscedastic means. Biometrics, 13: 359-364.

28. Golub IM, Greenwald RA, Zebrowski EJ \& Ramamurthy K (1978). The effect of experimental diabetes on the molecular characteristics of soluble rat collagen. Biochimica et Biophysica Acta, 534: 73-81.

29. McLennan S, Yue DK, Fisher E, Capogreco C, Heffernan S, Ross GR \& Turtle JR (1988). Deficiency of ascorbic acid in experimental diabetes. Relationship with collagen and polyol abnormalities. Diabetes, 37: 359-361.

30. Bensusan HB (1965). A novel hypothesis for the mechanism of cross-linking in collagen: Structure and chemistry of collagen. In: Harkness ND, Partridge SM \& Tristiam GR (Editors), Structure and Function of Connective and Skeletal Tissue. Butterworth, London, UK.

31. Yamaguchi F, Ariga T, Yoshimura Y \& Nakazawa H (2000). Antioxidative and anti-glycation activity of garcinol from Garcinia indica fruit rind. Journal of Agricultural and Food Chemistry, 48: 180-185.

32. Rao CN, Rao VH \& Sanjeevi R (1981). Effect of Biflavonoids on the mechanical and thermal properties of skin and tendon. Indian Journal of Biochemistry and Biophysics, 18: 224-228.

33. Meng J, Sakata N, Takebayashi S, Asano T, Futata T, Araki N \& Horiuchi S (1996). Advanced glycation end products of the Maillard reaction in aortic pepsin-insoluble and pepsin-soluble collagen from diabetic rats. Diabetes, 45: 1037-1043.

34. Wolff SP \& Dean RT (1987). Glucose autoxidation and protein modification. Biochemical Journal, 245: 243-250.

35. Ahmed MU, Thorpe SR \& Baynes JW (1986). Identification of N epsilon-carboxymethyllysine as a degradation product of fructose lysine in glycated protein. Journal of Biological Chemistry, 261 4889-4894.

36. Hicks M, Delbridge L \& Yue DK (1988). Increase in cross-linking of nonenzymatically glycosylated collagen induced by products of lipid peroxidation. Archives of Biochemistry and Biophysics, 268: 249254.

37. Fu MX, Requena JR, Jenkins AJ, Lyons TJ, Baynes JW \& Thorpe SR (1996). The advanced glycation end product, $N$ epsilon-(carboxymethyl)lysine, is a product of both lipid peroxidation and glycoxidation reactions. Journal of Biological Chemistry, 271: 9982-9986.

38. Kim YS, Kim BC, Song CY, Hong HK, Moon KC \& Lee HS (2001). Advanced glycosylation end products stimulate collagen mRNA synthesis in mesangial cells mediated by protein kinase $\mathrm{C}$ and transforming growth factor-beta. Journal of Laboratory and Clinical Medicine, 38: 59-68.

39. Odetti P, Pronzato MA, Noberasco G, Cosso L, Traverso N, Cottalasso D \& Marinari UM (1994). Relationship between glycation and oxidation related fluorescence in rat collagen during aging. An in vivo and in vitro study. Laboratory Investigation, 70: 61-67.

40. Sakata N, Meng J, Jimi S \& Takebayashi S (1995). Nonenzymatic glycation and extractability of collagen in human atherosclerotic plaques. Atherosclerosis, 116: 63-75

41. Fujimori E (1989). Cross-linking and fluorescence changes of collagen by glycation and oxidation. Biochimica et Biophysica Acta, 998: 105-110. 